\title{
The Magna Charta of Environmental Legislation: A historical look at 30 years of NEPA-Forest Service Litigation
}

\author{
Shorna R. Broussard ${ }^{\mathrm{a}, *}$, Bianca D. Whitaker ${ }^{\mathrm{b}, 1}$ \\ a Cornell University, Dept. of Natural Resources, Fernow Hall, Ithaca, NY 14853, United States \\ b Texas AEM University, Dept. of Wildlife and Fisheries Sciences, 210 Nagle Hall, TAMUS 2258, College Station, TX 77843, United States
}

\section{A R T I C L E I N F O}

Article history:

Received 25 April 2007

Received in revised form 30 September 2008

Accepted 5 December 2008

Keywords:

USDA Forest Service

National Environmental Policy Act

Environmental litigation

Environmental Assessment

Environmental Impact Statement

\begin{abstract}
A B S T R A C T
The National Environmental Policy Act (NEPA) of 1970 changed the landscape of natural resource management by requiring federal agencies to assess the environmental consequences of their proposed actions and to include the public in their decision-making processes. Of all federal agencies in the United States, the Forest Service prepares the most Environmental Impact Statements under NEPA. The U.S. Forest Service manages the National Forest System, public forestlands comprising approximately $9 \%$ of the United States land area. The overall objectives of this study were to (1) determine the litigants, success rates, and management activities disputed for NEPA litigation involving the Forest Service from 1970 to 2001 and (2) examine differences and patterns in cases among the U.S. District, Circuit, and Supreme Courts. Methods include a historical analysis of published court cases and results show an increasing trend in the number of NEPA-Forest Service cases in the federal courts. Environmental groups were the most common litigants in NEPA-Forest Service cases and timber harvesting, management plans, and endangered species were the subject of the majority of cases in both the U.S. District Court and the U.S. Circuit Court of Appeals. The Forest Service won a preponderance of cases in which they were involved with success rates of $60 \%$ in U.S. District Court, $57 \%$ in the U.S. Circuit Court of Appeals, and 100\% in the U.S. Supreme Court.
\end{abstract}

(c) 2008 Elsevier B.V. All rights reserved.

\section{Introduction}

The National Environmental Policy Act (NEPA) is often considered the Magna Charta of Environmental Legislation. NEPA requires an environmental review for every major action of the federal government in the United States (42 U.S.C. Section 4321). NEPA set broad interdisciplinary goals (Section 101) and established a set of procedures to meet those goals (Section 102). NEPA goals are as follows:

(1) fulfill the responsibilities of each generation as trustee of the environment for succeeding generations;

(2) assure for all Americans safe, healthful, productive, and aesthetically and culturally pleasing surroundings;

(3) attain the widest range of beneficial uses of the environment without degradation, risk to health or safety, or other undesirable and unintended consequences;

(4) preserve important historic, cultural, and natural aspects of our national heritage, and maintain, wherever possible, an environment which supports diversity and variety of individual choice;

\footnotetext{
* Corresponding author. Tel.: +1 607255 2149; fax: +1 6072550349 . E-mail addresses: srb237@cornell.edu (S.R. Broussard), bdcwhitaker@tamu.edu (B.D. Whitaker).

1 Tel.: +1979 8628582
}

(5) achieve a balance between population and resource use which will permit high standards of living and a wide sharing of life's amenities; and

(6) enhance the quality of renewable resources and approach the maximum attainable recycling of depletable resources.

NEPA procedures outlined in Section 102 contain the "actionforcing" provisions that ensure federal government agencies comply with the law. If a proposed action of federal government meets the threshold of a major federal action with significant environmental consequences, then an environmental analysis in the form of an Environmental Assessment (EA) or Environmental Impact Statement (EIS) and public input are required. When NEPA was first passed it was arguably the most comprehensive environmental policy in the United States in that it resulted in a level of environmental review for all federal agency actions; however it is not without its shortcomings.

One shortcoming of NEPA is that procedural requirements of the law have overtaken the more substantive environmental and interdisciplinary goals outlined above. Some have argued that the environmental planning process under NEPA has become more about the planning process than about whether adequate information about alternatives is used to make environmentally sound decisions (Bausch, 1991; Salk et al., 1997; Bailey, 1997; Phillips and Randolph, 2000). Other criticisms of NEPA are centered on the failure to consistently and uniformly: (1) engage the public early in the planning process, (2) apply rigorous science in evaluating alternatives, (3) 
achieve substantive environmental outcomes, and (4) apply a common decision analysis framework such as risk assessment or ecosystem management in the decision-making and alternative evaluation process (Salk et al., 1997; Shepherd and Bowler, 1997; Phillips and Randolph, 2000; Ugoretz, 2001; West, 2003; Fairbrother and Turnley, 2005).

Concerns have also been raised regarding the time and financial commitment involved in implementing NEPA and the consequences of those costs on managing natural environments (Jones and Taylor, 1995; USDA Forest Service, 2002; West, 2003). Limited funds and personnel time are often diverted to planning which leaves fewer resources for environmental monitoring and project management and implementation. For example, West (2003) stated that 5\% of Forest Service budget is dedicated to monitoring and planning; of that, the majority of funds are used for planning to meet NEPA requirements. There is little in the way of funds to conduct ecological monitoring, which West (2003) found is deeply lacking on federal rangelands in the United States.

In the early 1970's Cutler (1972) predicted that litigation would increase because of NEPA's procedural requirements. This prediction has certainly materialized. While the federal government enjoys high success rates in litigation brought against it by environmental and commodity-production oriented interests (Alden and Ellefson, 1997; Jones and Taylor, 1995; Wenner, 1982; Wenner, 1983), the effects of the litigation cannot be discounted and is the subject of this paper. Courts in the United States significantly influence the interpretation of policies enacted by the U.S. Congress and carried out by federal agencies that manage $242,800,000$ ha $(600,000,000$ acres $)$ of public land covering $29 \%$ of the U.S. land area. One such agency, the United States Forest Service, manages public forestlands known collectively as the National Forest System. The U.S. Forest Service manages roughly $9 \%$, or $77,290,000$ ha $(191,000,000$ acres $)$, of lands in the United States.

The overall objectives of this study were to (1) determine the litigants, success rates, and management activities disputed for NEPA litigation involving the Forest Service from 1970 to 2001 and (2) examine differences and patterns in cases and decision-making among the U.S. District, U.S. Circuit Court of Appeals, and U.S. Supreme Court. The federal court system of the United States court system is organized into 3 primary levels: the U.S. District Court, U.S. Circuit Court of Appeals, and the U.S. Supreme Court. Federal cases begin in the District Courts and then if appealed, proceed to the Circuit Court. If the case is appealed again, the court of last resort is the U.S. Supreme Court. Analysis was conducted separately for each court level.

\subsection{History of NEPA, U.S. Forest Service, and the Courts}

Litigation on environmental issues was present prior to NEPA; however, passage of NEPA significantly affected the amount of such litigation. Due to its procedural requirements federal agencies were held responsible for considering alternative management methods and the environmental consequences of their actions. NEPA regulations require several levels of environmental review. The lowest level of environmental review is a categorical exclusion, where the agency determines that the proposed action will not have a significant environmental impact. If the proposed action will have a significant environmental impact, an Environmental Assessment or Environmental Impact Statement is required. An EIS, the longest and most detailed review, is required for any major federal action that can cause significant environmental impacts.

The Forest Service regularly files more EIS's than any other federal agency of government according to a report published by the U.S. Forest Service (USDA Forest Service, 2002). While the report does not specify the time period that the average is based on, the Forest Service produces approximately 120 EIS's/year, which is higher than the yearly average of any other federal agency (USDA Forest Service, 2002). The Forest Service must complete EIS's for Land and Resource
Management Plans for each national forest as required for management planning under the National Forest Management Act (NFMA) (16 U.S.C. 1600). Virtually all management activities that the Forest Service conducts (e.g. timber harvest, trail maintenance and construction, etc.) are tied to NEPA environmental review requirements. It is the adequacy of these environmental review documents that is the source of litigation under NEPA. The Forest Service has an Administrative Appeals process that allows the public an opportunity to appeal an agency decision to the Forest Service, prior to formal litigation in the courts. Many authors have researched the administrative appeals process, and the reader can consult these studies for further detail (see Bobertz and Fischman, 1993; Coulombe, 2004; Jones and Taylor, 1995; Mortimer et al., 2004; Teich et al., 2004). The current study does not focus on the administrative appeals process, but rather on postadministrative appeals that are legal cases in the federal court system in the United States. The current study builds upon these studies by analyzing NEPA-Forest Service Litigation in the District, Circuit, and Supreme Courts over the three decades that have passed since the laws' inception.

To date, there have been three comprehensive studies documenting NEPA-Forest Service Litigation. Alden and Ellefson's (1997) report looked broadly at litigation under all environmental laws affecting the Forest Service in the federal Supreme, Circuit, and District Courts. Cases involving NEPA proved to be the most common type of litigation throughout the 1980's (Alden and Ellefson, 1997). This study showed a higher success rate for pro-environmental protection litigants than for pro-development and use litigants. However, the Forest Service had a higher success rate than the rates for all other litigant types, even when the agency represented a pro-development and/or pro-use position. Malmsheimer et al.'s (2004) study of national forest litigation focused on the U.S. Circuit Court of Appeals and six federal environmental laws, including NEPA. Court cases concerning national forest management increased over the time period of 1970 to 2001 and most were NEPA based (Malmsheimer et al., 2004). This trend was also found in Keele et al.'s (2006) study which focused on cases (19892002) brought against the Forest Service for land management decisions of the agency. This study found that NEPA, NFMA, and ESA (Endangered Species Act) served as the statutory basis for the majority of land management litigation (Keele et al., 2006). Despite the high success rate of the Forest Service in environmental litigation (57\%) in the Circuit courts and land management litigation (58\%) in the federal courts, the increasing trend in the number of court cases corresponds to increased judicial review of management decisions of the Forest Service (Malmsheimer et al., 2004; Keele et al., 2006).

\subsection{Environmental litigation and interest groups}

Litigation initiated by environmental interest groups, such as the Sierra Club and the Audubon Society, has increased significantly over time (Alden and Ellefson, 1997; Cutler, 1972; Jones and Taylor, 1995; Wenner, 1982; Wenner, 1983). This increase coincides with the marked growth in the total number of environmental groups nationwide, as well as membership increases since the 1970's (Berry, 1997). Environmental groups and individual citizens are the most common plaintiffs in Forest Service environmental litigation (Malmsheimer et al., 2004). Commodity driven interests (e.g. timber, mining, and commercial fishing) have a significantly lower success rate when compared to environmental groups (Alden and Ellefson, 1997; Jones and Taylor, 1995). The Forest Service (Alden and Ellefson, 1997; Malmsheimer et al., 2004) and the federal government in general (Wenner, 1983) remain the most successful parties in environmental litigation.

Interest groups often use the judicial system to halt what they consider to be environmentally unsound projects (Blumm and Brown, 1990). The ensuing effects of litigation by interest groups have been widespread, and such litigation has been an effective means of 
changing U.S. bureaucracies (Barker, 1967; Jones and Taylor, 1995; Wasby, 1983; Wenner, 1983). The courts have provided economic relief, injunctions on agency actions, and conservation relief to various environmental groups (Alden and Ellefson, 1997; Cutler, 1972; Hassler and O'Connor, 1986). Federal agencies frequently reconsider alternative management options rather than go to court due to the economic costs as well as the time associated with litigation (Cutler, 1972; Jones and Taylor, 1995). NEPA gave interest groups a legal basis on which to sue. Interest groups have used NEPA to move the Forest Service toward non-commodity uses of national forests. For example, previous research has shown that NEPA decisions favor those litigants seeking non-consumptive uses of national forests than those seeking changes in consumptive uses (Jones and Taylor, 1995). Litigation is an "attractive change agent" for interest groups and litigation is used most frequently by environmentalists and most often to block commodity production activities (Jones and Taylor, 1995, p. 332). Successful litigation brought against the Forest Service by environmental groups results in either changes in management activities of the agency or, if the litigation is unsuccessful, it serves as a catalyst to launch the issue into the policy arena for further resolution (Jones and Taylor, 1995).

\section{Case analysis methodology}

We conducted a historical case analysis of all published federal court cases between 1970 and 2001 in which the USDA Forest Service was a litigant and NEPA was a subject of the litigation. While many court options are published, published cases do not represent the entirety of cases presented before the courts (Keele et al., 2006). Additionally, readers should note that while some Circuit Court of Appeals cases result from published District Court cases, some do originate from unpublished District Court Cases. For the purposes of this research, we utilized published cases available from Lexis-Nexis. A database of all cases included in the study was created and analyzed using SPSS (Statistical Package for the Social Sciences) version 15.0 for Windows (SPSS Inc., 2006). All NEPA court cases involving the Forest Service were coded according to six criteria: (1) Federal court where the case was adjudicated (District, Appellate, Supreme); (2) Case citation; (3) Type of plaintiff and defendant (litigant); (4) Management activity or main subjects of the litigation; (5) Date; and (6) Outcome.

Litigants, other than the Forest Service, were identified by the first litigant listed in the case. The litigants were coded into 1 of 7 categories based on the interests they represented in the specific case: Environmental Groups, Individuals, User Groups, Local and State Governments, Native American Interests, Industry Interest Groups, and Industry. Environmental Groups were dedicated to preserving and protecting the environment such as Sierra Club, Audubon Society, and Friends of the Earth. Individuals were people acting on their own behalf, whether interested in preserving the environment or in using it. User Groups were those interested in utilizing the area for recreational purposes, such as the Utah Shared Access Alliance and the Montana Snowmobile Association. Local and State Governments included counties, cities, and states. Native American Interests were parties involved or associated with Native American Tribes, such as the Northwest Indian Cemetery Protective Association and Hopi Indian Tribe. Industry Interest Groups, such as the Wyoming Timber Industry Association represented the interests of industry. The Industry category included companies with vested interests in utilizing an area for business purposes, such as the American Timber Company and Western Radio Services Company, Inc.

NEPA environmental planning requirements were coded as either Inadequate EA or EIS, or No EA or EIS. The "Inadequate EA or EIS" code usually questioned the consideration of alternative plans of action. Litigation pertaining to failure to prepare an EA or an EIS is represented by the category "No EA or EIS."
The subject matter(s) disputed in each case were coded into categories and the categories were not mutually exclusive. Management activities were coded into 10 categories and included: Timber Harvesting, Management Plans, Endangered Species, Roads/Trails, Recreation, Wetlands/Water/Rivers, Wildlife Management, Mining/Oil and Gas, Pesticides/Herbicides, and Native American Lands. Cases were coded "Timber Harvesting" if litigation involved activities such as old-growth timber harvesting, clearcutting, and other silvicultural methods. The "Management Plans" code was used to classify disputes over Land Resource Management Plans (LRMP) prepared under the National Forest Management Act (16 U.S.C. Section 1600) legislation. The "Endangered Species" category contained litigation concerning the Endangered Species Act (ESA) (16 U.S.C. Section 1531). The "Roads/ Trails" code included any activity pertaining to construction or maintenance of roads or trails. The code "Recreation" involved rights to use public lands for activities such as hunting, hiking, skiing, and snowmobiling. "Wetlands/Water/Rivers" pertained to activities affecting water resources or wetland areas in any manner, including Wild and Scenic Rivers (16 U.S.C. Section 1271). The "Wildlife Management" code was used for activities dealing with species not listed as threatened or endangered and their habitat. For example, the cases dealing with the cougar (Felis concolor) and black bear (Ursus americanus) would be included under this code, while northern spotted owl (Strix occidentalis) cases would fall under the "Endangered Species" category. "Mining/Oil and Gas" included activities dealing with mining or drilling permits and mineral rights. "Pesticides/ Herbicides" dealt with the use of such chemicals on natural forest lands. Cases were coded "Native American Lands" if they concerned proposed uses on Native American-designated sacred lands, whether on Tribal lands or not.

Outcomes were coded into three categories: (1) Plaintiff, if the plaintiff in the case won; (2) Defendant, if the defendant in the case won; or (3) Other judgments, if there was a partial ruling or a reserved ruling. The outcomes are representative of published court cases during the time period of the study (1970-2001). Readers should note that some cases are settled out of court, some cases are unpublished, and some outcomes are further adjudicated in the court following a decision. For example, a Circuit Court of Appeals decision that overturned a District Court ruling would not be represented here if the case was unpublished. Additionally, published cases reflect the final outcome in the majority of cases, but note that adjudication beyond the initial decision is sometimes possible, particularly in the case of preliminary injunctions.

\section{Results and analysis}

Based on the historical case analysis, we present results related to litigants and outcomes, management activities disputed, and trends within the courts. There were a total of 291 published cases involving NEPA and the Forest Service for the years 1970 through 2001 (Fig. 1). Over this time period, 179 cases were heard in the District Courts. There were 108 published cases in the Circuit Court of Appeals, and 4 cases were litigated in the U.S. Supreme Court.

\subsection{Litigants and outcomes}

Because the Forest Service was a defendant in $95 \%$ of the cases, we present the results from the perspective of the plaintiffs bringing lawsuits against the agency. In 16 cases the Forest Service was an appellant, when it appealed an unfavorable outcome at the District or Circuit Court levels. For these cases, 12 were in the Circuit Court of Appeals and 4 were in the Supreme Court (see Fig. 2). The most litigious groups were Environmental Groups, Individuals, and User Groups.

Fig. 2 also provides outcomes of NEPA-Forest Service Litigation by litigant type for plaintiffs/appellants. At the District Court level, the 


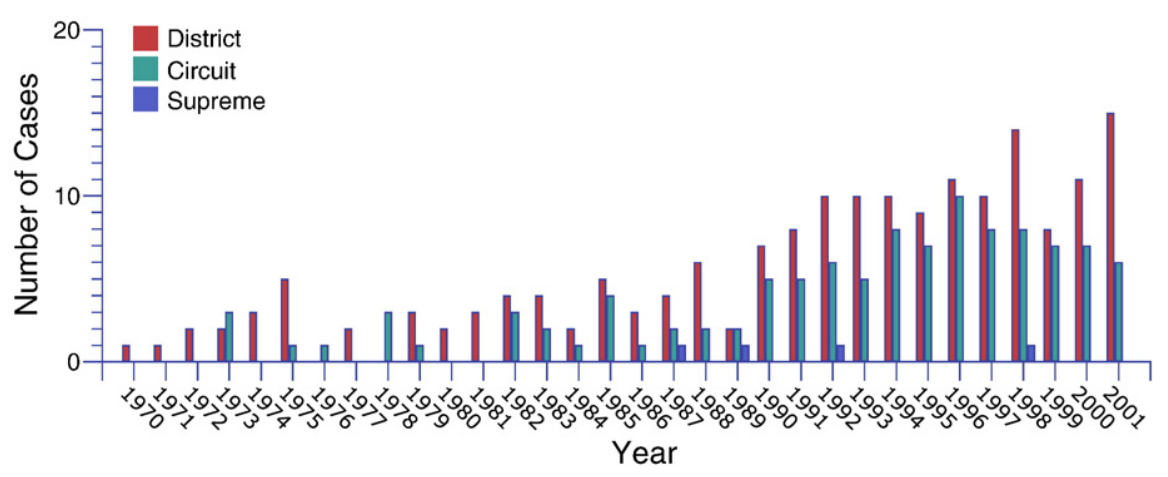

Fig. 1. Number of USDA Forest Service NEPA cases January 1970-December 2001.

Forest Service won $60 \%$, lost $20 \%$, and had other judgments in $20 \%$ cases brought against them. Environmental Groups were the main litigants, serving as plaintiffs in $61 \%$ of NEPA-Forest Service cases at the District Court level. Individuals were plaintiffs in $16 \%$ of the cases and User Groups in $8 \%$ of the cases. At the U.S. Court of Appeals level, the Forest Service won $57 \%$ of the cases, lost $26 \%$, and had other judgments in $17 \%$ of cases brought against them by the plaintiffs in Fig. 2. Environmental Groups were plaintiffs in $66 \%$ of the appellate court cases, Individuals in 13\%, and User Groups in 7\%. Appellate court cases were centered in the Pacific Northwest and Inter-mountain West. A majority (61\%) of appellate court cases were heard in the Ninth Circuit Court of Appeals (Alaska, Arizona, California, Hawaii, Idaho, Montana, Nevada, Oregon, Washington), while $12 \%$ were litigated in the Tenth Circuit Court of Appeals (Colorado, Kansas, New Mexico, Oklahoma, Utah, Wyoming). The next highest region, the 8th Circuit Court of Appeals, had only 7\% of NEPA-Forest Service cases.

Four cases involving the Forest Service and NEPA have reached the U.S. Supreme Court. The agency was the appellant in and prevailed in all four U.S. Supreme Court cases. Environmental groups were appellees in three of these cases, and the Northwest Indian Cemetery Protection Association was the appellee in the fourth case.

\subsection{Management activities disputed}

The majority of NEPA-Forest Service cases were brought to court due to a perceived inadequacy of an EA or EIS that the Forest Service

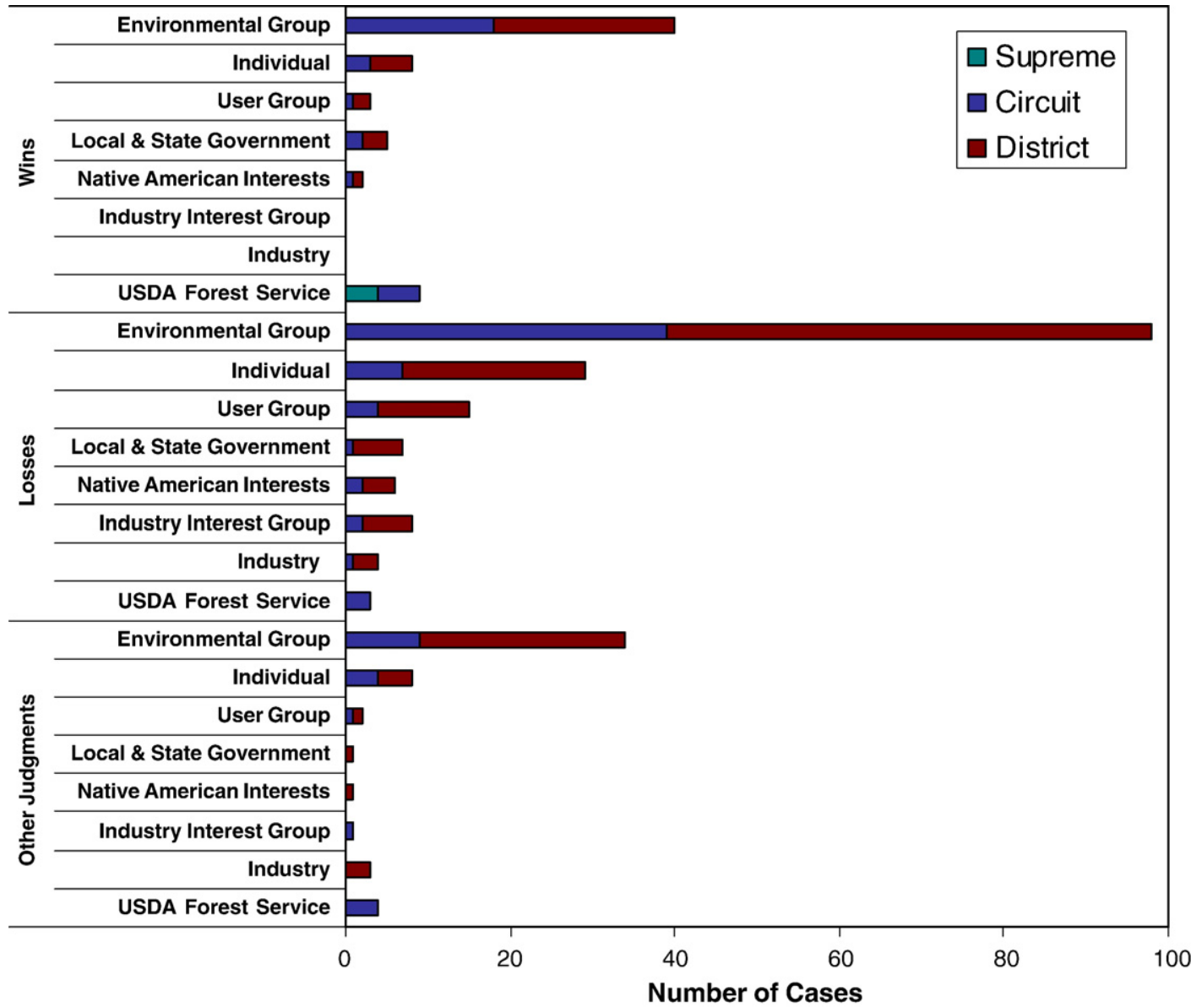

Fig. 2. Orientation of plaintiffs/appellants and case outcomes in all federal court cases (Supreme, Circuit, District) involving USDA Forest Service and NEPA, $1970-2001$. 


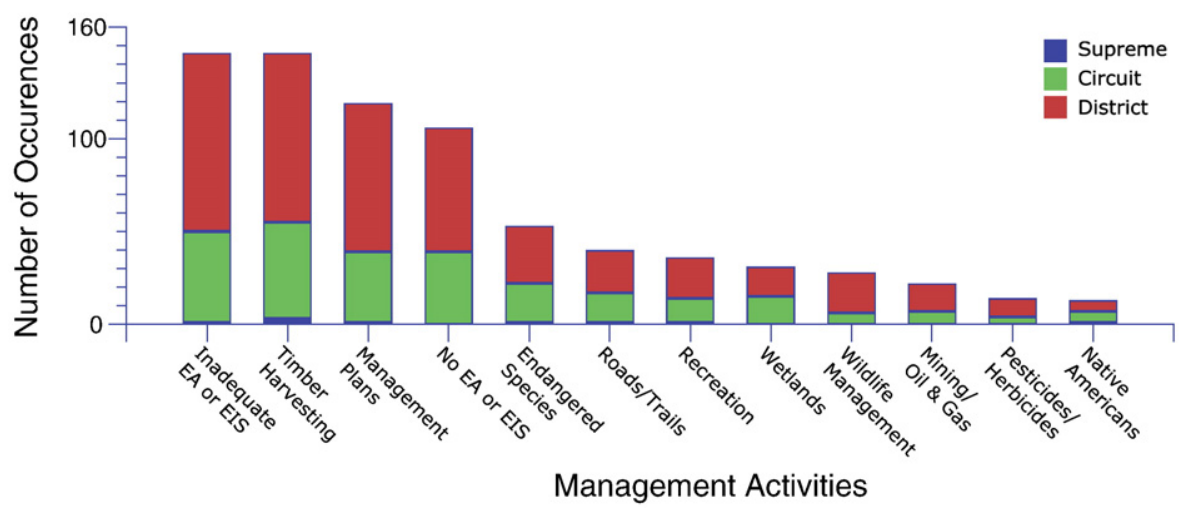

Fig. 3. Distribution of management activities disputed in USDA Forest Service NEPA cases by court level, 1970-2001.

prepared or because an EA or EIS was not prepared by the agency (Fig. 3). At the District Court level, $36 \%$ of the cases involved an Inadequate EA or EIS and 55\% involved cases where plaintiffs argued that an EA or EIS should have been prepared. For appellate cases that involved NEPA environmental planning claims, 48\% disputed the adequacy of a prepared EA or EIS and 35\% of the cases disputed the decision not to prepare an EA or EIS. One Supreme Court case involving the Forest Service and NEPA during this study's time period was in relation to the inadequacy of an EA/EIS. Eighteen Circuit and 16 District court NEPA-Forest Service cases did not relate specifically to an EA or EIS. In those cases, plaintiffs typically made general claims that the Forest Service violated NEPA but did not base that claim on an EA or EIS (or that one should have been prepared). Other examples of non-EA/EIS NEPA cases include a claim that the Forest Service failed to solicit input properly or cases where the date of the Record of Decision was in question due to the statute of limitations.

The top five management activities disputed in NEPA-Forest Service cases at the District Court level were Timber Harvesting $(n=93)$, Management Plans $(n=83)$, Endangered Species $(n=31)$, Roads/Trails $(n=23)$, Recreation $(n=23)$, and Wildlife Management $(n=23)$ (Fig. 4). Of the 179 cases at the District Court level, Timber Harvesting was the subject in $51 \%(n=93)$ of all cases, Management Plans in $45 \%(n=83)$, Endangered Species in $17 \%(n=31)$, Roads/Trails in $13 \%(n=23)$, Recreation in $13 \%(n=23)$, and Wildlife Management in $13 \%(n=23)$. Environmental Groups most often disputed Timber Harvesting $(59 \%, n=66)$ and Management Plans $(45 \%, n=50)$ in the cases they were involved in. Individuals disputed Timber Harvesting in 55\% $(n=16)$ and Management Plans in 52\% $(n=15)$ of the cases they litigated. User Groups were involved most often in cases concerning Recreation $(53 \%, n=8)$.
For the Circuit Court of Appeals, the top five management activities were: Timber Harvesting ( $n=52)$, Management Plans $(n=40)$, Endangered Species $(n=21)$, Roads and Trails $(n=17)$, and Wetlands/Water/ Rivers $(n=16)$ (Fig. 5). Environmental Groups disputed Timber Harvesting in $45 \%(n=34)$ and Management Plans in $36 \%(n=27)$ of the cases they were involved in. A majority of cases disputed by Individuals concerned Timber Harvesting $(50 \%, n=7)$, Endangered Species $(29 \%, n=4)$, and Management Plans $(21 \%, n=3)$. User Groups most frequently litigated cases involving Management Plans (25\%, $n=2$ ).

In the four Supreme Court cases, the Forest Service appealed, therefore, was an appellant in cases involving the following subject matters: Timber Harvesting $(n=3)$, Inadequate EA or EIS $(n=1)$, Management Plans $(n=1)$, Roads/Trails $(n=1)$, Wetlands/Water/Rivers $(n=1)$, Recreation $(n=1)$, and Native American Interests $(n=1)$. Three of the cases involved two of the subject matters listed, while the fourth involved three of these.

Disputes concerning endangered species experienced a drop in the mid-to-late 1990's. A total of 53 endangered species cases were included in the study, with Timber Harvesting $(n=30)$ and Management Plans $(n=14)$ being the most frequent management activities disputed with them. Of the 53 endangered species cases, 30 involved the following three species: the northern spotted owl $(n=11)$, the grizzly bear $(n=10)$, and the red-cockaded woodpecker (Picoides borealis) $(n=9)$. The other 23 endangered species cases involved species such as the bald eagle (Haliaeetus leucocephalus) $(n=2)$, the prairie dog (Cynomys ludovicianus) ( $n=1)$, the gray wolf (Canis lupus) $(n=4)$, and various fish species. Cases involving three endangered species that were the subject of most NEPA-Forest Service Litigation experienced a marked decrease after 1990: the last northern spotted

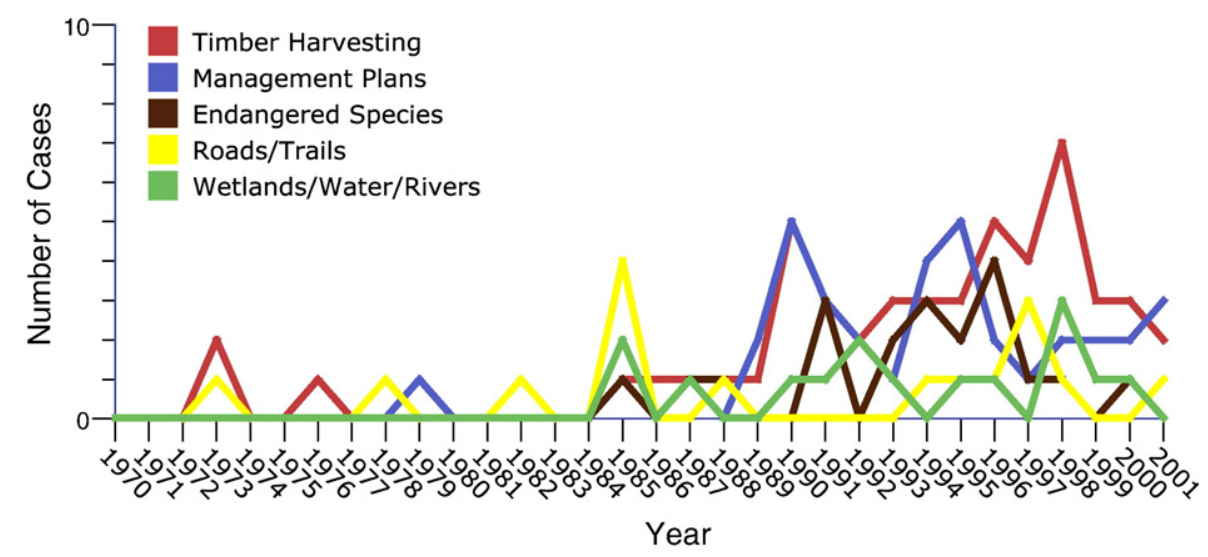

Fig. 4. Top 5 management activities disputed in USDA Forest Service NEPA cases for U.S. District Courts, 1970-2001. 


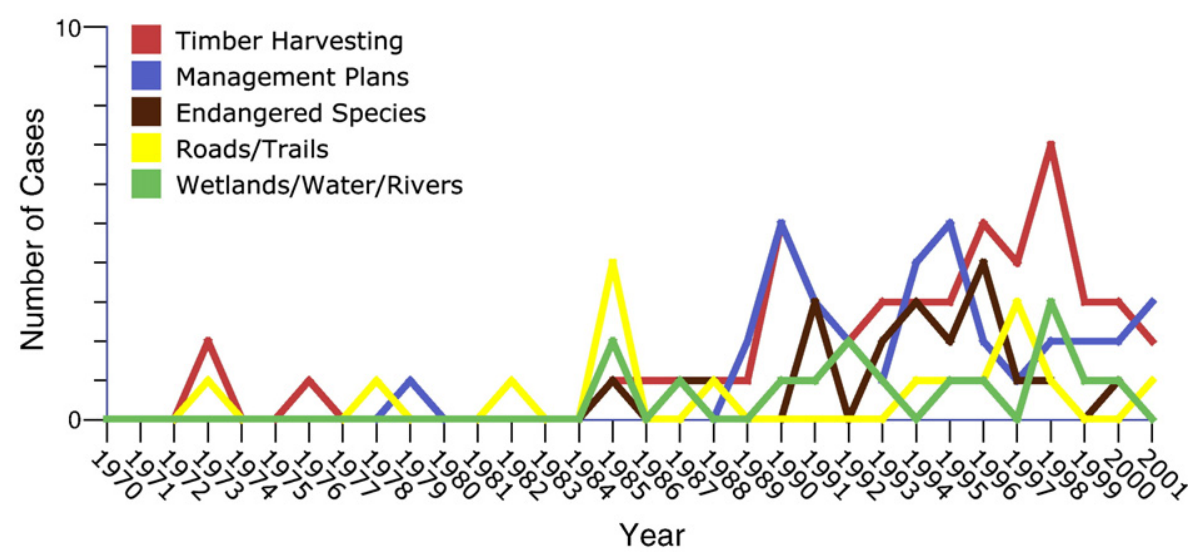

Fig. 5. Top 5 management activities disputed in USDA Forest Service NEPA cases for U.S. Circuit Court of Appeals, 1970-2001.

owl case was litigated in 1996, the last grizzly bear case in 1997, and the last red-cockaded woodpecker case in 1993.

The Forest Service won a total of 31 (58\%) of the Endangered Species cases ( 4 of the northern spotted owl cases, 8 of the grizzly bear cases, 3 of the red-cockaded woodpecker cases, and 16 of the others). Cases involving endangered species were disputed in the regions of the United States where the species occur. However, $50 \%$ of the endangered species cases occurred in the western District Courts of Washington $(n=4)$, Montana $(n=2)$, California $(n=1)$, and Wyoming $(n=1)$ and in the Ninth Circuit Court of Appeals $(n=7)$, which includes all of the aforementioned states except Wyoming. The red-cockaded woodpecker cases were litigated mainly in the southeastern U.S. in the Districts of Georgia $(n=2)$, Texas $(n=2)$, and D.C. $(n=3)$ and in the 5th $(n=1)$ and $11^{\text {th }}(n=1)$ Circuit Courts of Appeals, which cover most of the southeastern states.

\section{Discussion}

The fact that NEPA-Forest Service Litigation has steadily increased during initial decades of its passage has several implications. First, court proceedings are both lengthy and adversarial. The adversarial nature of court proceedings dampens the ability to communicate and solve issues such that both sides can win. When a group or individual opposes a project level decision of the Forest Service, the appeals and litigation options are a disincentive to collaboration (USDA Forest Service, 2002). As long as the courts are used as a tool to attempt to cause agency change, increased time will be spent in court.

Secondly, environmental interest groups were involved in more NEPA-Forest Service cases than all other interest groups combined. This is the result of many factors such as dissatisfaction with agency planning, the perceived lack of alternative plans of actions, or feelings that the agency failed to consider public concerns (USDA Forest Service, 2002). When environmental groups brought the Forest Service to court, they had a lower success rate than did the Forest Service. Despite the low success rate of environmental groups, their influence on Forest Service actions has been notable in terms of the costs associated with litigation. If more time is spent in court, less time is spent managing the forests, and fewer funds are available to spend on forest management activities. Threat of litigation has caused the Forest Service to reconsider alternatives to proposed management actions or to "bullet proof project planning" in order to avoid the time and financial costs associated with litigation (Jones and Taylor, 1995; USDA Forest Service, 2002, p. 36).

There is also evidence that procedural requirements of federal environmental laws such as NEPA can constrain the Forest Service's ability to address declining forest health of national forests (USDA Forest Service, 2002) and rangelands (West, 2003). Ecosystem management (Phillips and Randolph, 2000) and risk assessment
(Fairbrother and Turnley, 2005) approaches have been advocated as a way to ensure that substantive ecological goals are considered in environmental planning, not just the procedural requirements that lead to a particular alternative being selected by the agency.

Thirdly, timber harvesting activities and management plans were the subject of the most disputes in both the U.S. District and Circuit Courts. Thus, environmental groups, who bring the majority of NEPA cases against the Forest Service, appear to be greatly dissatisfied with management planning and timber harvesting activities of our nation's national forests. This is particularly evident in the Oregon District and the Ninth Circuit, where national forests and environmental groups are both abundant.

\section{Conclusions}

Public land management continues to be a controversial arena, in particular timber harvesting decisions. While this research is consistent with previous research which has established a high success rate of the Forest Service in environmental litigation (Alden and Ellefson, 1997; Malmsheimer et al., 2004; Keele et al., 2006), planning decisions are often at the center of NEPA-Forest Service Litigation. The perceived inadequacy of planning documents such as environmental assessments, environmental impact statements, and forest management plans are commonly the source of litigation brought against the Forest Service. Most cases are complex and involve multiple management activities and the most common primary litigants are environmental groups. While the courts continue to be used as a platform for resolving disputes over agency planning and management, this study confirms, as others have as well (Keele et al., 2006), that the increasing trend in Forest Service environmental litigation has been somewhat stunted during the early years of the Bush Administration. This is likely indicative of a new trajectory for environmental litigation involving the Forest Service, but only future research will reveal the true nature of this emerging trend. Additional thoughts regarding future research are detailed below.

\section{Limitations and future research}

Throughout this investigation into the National Environmental Policy Act and the U.S. Forest Service, it has been noted that there is still much more to learn. A study of the economic ramifications may also prove to be worthwhile in realizing the full effects of litigation. Knowing where the financial resources are distributed in management decisions and how those are diverted to litigation could be key to answering questions concerning the ongoing efforts to find a balance in the management of our National Forests. Studying the effects of litigation on actual management practices, or on-the-ground management decisions, could also aid in discovering how time 
resources are allocated. Future research should also address multiple litigants in cases to provide an even broader scope of NEPA litigation; one limitation of the current study is that the methodology entailed only coding the first litigant in the court case, not all litigants that may have been involved in a particular case. Additionally, future research could examine unpublished as well as published court cases which can further build the body of knowledge around U.S. Forest Service NEPA litigation; this study only examined published court cases. Future research might also follow specific cases through the court system beginning at the District Court; this would provide researchers with a full understanding of what is occurring in the judicial system regarding NEPA and the Forest Service. Additionally, an in-depth study on the various litigant/interest groups would be beneficial. Looking at the various groups and their purposes within each plaintiff type (e.g. Environmental Groups, User Groups) could provide useful information, such as how they obtain and allocate resources such as money, time, and political influence.

\section{References}

Alden, A.M., Ellefson, P., 1997. Natural Resource and Environmental Litigation in the Federal Courts: a Review of Parties, Statutes and Circuits Involved (Staff Paper Series No.125). University of Minnesota, College of Natural Resources and the Agricultural Experiment Station, St. Paul, MN.

Bailey, J., 1997. Environmental impact assessment and management: an unexplored relationship. Environmental Management 21 (3), 317-327.

Barker, L.J., 1967. Third parties in litigation: a systemic view of the judicial function. The Journal of Politics 29, 41-69.

Bausch, C., 1991. Achieving NEPA's purpose in the 1990s. Environmental Professional 13, 95-99.

Berry, J.M., 1997. The Interest Group Society, Third edition. Longman, New York.

Blumm, M.C., Brown, S.R., 1990. Pluralism and the environment: the role of comment agencies in NEPA litigation. Harvard Environmental Law Review 14, 277-309.

Bobertz, B.C., Fischman, R.L., 1993. Administrative appeal reform: the case of the Forest Service. University of Colorado Law Review 64, 371-456.

Coulombe, M.J., 2004. Exercising the right to object: a brief history of the Forest Service appeals process. Journal of Forestry 102 (2), 10-13.
Cutler, M.R., 1972. A study of litigation related to management of forest service administered lands and its effect on policy decisions. Part two: a comparison of four cases. Dissertation Abstracts International 33 (11), 5086B (UMI No. AAT 7312697).

Fairbrother, A., Turnley, J.G., 2005. Predicting risks of uncharacteristic wildfires: application of the risk assessment process. Forest Ecology and Management 211, 28-35.

Hassler, G.L., O'Connor, K., 1986. Woodsy witchdoctors versus judicial guerrillas: the role and impact of competing interest groups in environmental litigation. Environmental Affairs 13, 487-520.

Jones, E.S., Taylor, C.P., 1995. Litigating agency change: the impact of the courts and administrative appeals process on the Forest Service. Policy Studies Journal 23 310-336.

Keele, D.M., Malmsheimer, R.W., Floyd, D.W., Perez, J.E., 2006. Forest Service land management litigation 1989-2002. Journal of Forestry 104 (4), 196-202.

Malmsheimer, R.W., Keele, D., Floyd, D.W. 2004. National Forest litigation in the US Courts of Appeals. Journal of Forestry 102 (2), 20-25.

Mortimer, M.J., Scardina, A.V., Jenkins, D.H., 2004. Policy analysis and National Forest appeal reform. Journal of Forestry 102 (2), 26-32.

Phillips, C.G., Randolph, J., 2000. The relationship of ecosystem management to NEPA and its goals. Environmental Management 26 (1), 16-20.

Salk, M.S., Tolbert, V.R., Dickerman, J.A., 1997. Guidelines and techniques for improving the NEPA process. Environmental Management 23, 467-476.

Shepherd, A., Bowler, C., 1997. Beyond the requirements: improving public participation in EIA. Journal of Environmental Planning and Management 40 (6), 725-738.

SPSS, Inc., 2006. Statistical Package for the Social Sciences 15.0 for Windows. PrenticeHall, Englewood Cliffs, NJ.

Teich, M.R., Vaughn, J., Cortner, H.J., 2004. National trends in the use of Forest Service administrative appeals. Journal of Forestry 102 (2), 14-19.

Ugoretz, S.M. 2001. Towards a new model of environmental review: preparing the US National Environmental Policy Act for new management paradigms. Impact Assessment and Project Appraisal 19 (1), 3-8.

USDA Forest Service, 2002. The Process Predicament: How Statutory, Regulatory, and Administrative Factors Affect National Forest Management. USDA Forest Service, Washington, DC, 40 pp.

Wasby, S.L., 1983. Interest groups and litigation. Policy Studies Journal 11, 657-670.

Wenner, L.M., 1982. The Environmental Decade in Court. Indiana University Press, Bloomington, IN.

Wenner, L.M., 1983. Interest group litigation and environmental policy. Policy Studies Journal 11, 671-683.

West, N., 2003. History of rangeland monitoring in the U.S.A. Society and Natural Resources 17, 495-545. 